Article

\title{
The Impact of Labor Union Influence on Corporate Social Responsibility
}

\author{
Hong-Min Chun and Sang-Yi Shin * \\ School of Business, Chungbuk National University, Cheongju-si 28644, Korea; hmchun@cbnu.ac.kr \\ * Correspondence: ssyend@naver.com; Tel.: +82-43-261-2349
}

Received: 18 May 2018; Accepted: 6 June 2018; Published: 8 June 2018

\begin{abstract}
This study examines the effects of labor union influence on the corporate social responsibility (CSR) of Korean firms, which is regarded as a pertinent sustainable factor to meet the various demands of the organizations around a firm. Further, this paper implies that labor unions might be part of a group of stakeholders that affect firms' CSR activity. The empirical results suggest labor union existence as well as the labor unionization ratio is negatively associated with firms' CSR activity. Additionally, this negative association is more pronounced for non-owner manager firms. Additional robustness tests using quantile regression, two-stage least squares (2SLS) regression, and the Heckman two-step analysis support the above findings. Therefore, we conclude that labor unions might cooperate with non-owner managers to decrease firms' CSR activity because decreasing CSR expenditure makes for a favorable wage negotiation process that advocates labor unions' rent seeking behavior and non-owner managers' agreement with labor unions in terms of business performance during their tenure.
\end{abstract}

Keywords: labor union; sustainable; non-owner manager; corporate social responsibility (CSR)

\section{Introduction}

This study examines whether labor unions affect firms' corporate social responsibility (CSR) in the Korean market. Specifically, this paper uses firm-year level labor union existence and the labor unionization rate as proxies for labor union influence and the Korean Economic Justice Institute (KEJI) index level as a proxy for CSR, and examines the labor union effects on firms' CSR activity, divided into owner manager and non-owner manager groups.

For instance, Carroll [1] defined CSR as corporate integrated responsibilities encompassing the economic, legal, ethical, and discretionary expectations the society has of organizations. Prior CSR-related literature documented CSR as a pertinent firm strategy to enhance the consumer perception of product quality [2] and lower the cost of capital costs [3,4]. In other words, extant studies on CSR suggest CSR activity could be firms' sustainable factor for survival in the near future [5]. However, since different stakeholders may have different objectives, as well as decision making horizons, it is worthwhile to study the relationships between the different stakeholder types and the firms' social responsibility for sustainability. At the same time, other studies emphasized the role of organizational factors, such as slack resources [6] and firm size [5]. Further, prior studies investigate managerial ownership [7], foreign ownership [8], institutional ownership [9], and board structure [7] using CSR activity. We extend this stream of literature by examining another important stakeholder group around the firm: labor unions.

Workers and unions may influence decision making directly by obtaining representation on boards through share ownership or, unofficially, by engaging in activities such as strikes and political lobbying as a part of the collective bargaining process In line of this research, Sulkowski et al. [10] noted that firms can play a role in confusing stakeholders and promote partnerships to create sustainable 
value shared with stakeholders which called as shaking stakeholders. So, firms can engage with stakeholders both internally, such as employee, and external, such as suppliers as well as consumers. Freeman and Medoff [11] show that labor unions encourage shirking, increase bargaining for wages above the equilibrium level, and lead to lower employee productivity due to strike action. Numerous U.S.-based labor union studies advocate that labor unions are counterproductive to firms because these rent-seeking agents constrain managers in making sub-optimal choices [12-14]. Specifically, Chen et al. [12] suggest that labor unions can lower operating flexibility, which can increase firms' cost of equity capital. Therefore, firms with labor unions suffer from higher bid-ask spreads and lower analyst followings [15], produce less valuable $R \& D$ (research and development) investments and hinder innovation [16] or higher reported earnings by real earnings management [17]. Conversely, other labor union studies argue labor unions could monitor the manager as an internal monitoring mechanism [18-20] and influence the production of superior financial information by demanding higher audit quality and better internal control systems [21,22].

In this paper, we focus on the role of labor unions on firms' CSR activity. Ex-ante, labor union influence might be positively associated with CSR if labor unions might play a constructive role to enhance CSR activity with the manager. On the other hand, labor union influence might be negatively associated with CSR if labor unions push managers to decrease CSR activity so that this rent seeking behavior increases wage premiums (however, not all reduction of CSR expenditures can be seen as evidence of labor union' rent-seeking) [23]. For example, the Hyundai Unions have been striking for six consecutive years in year 2012 2017. Last year, the strike caused a production disruption of 142,000 units and 3.1 billion dollars. The irresponsible strike by the Hyundai Unions has worsened the overall competitiveness of the domestic auto industry. Korea's ranking of global automobile production rallied from 5th to 6th place due to India's biggest strikes last year. The production disruption caused by the union strike and rejection of specialists this year is estimated at 38,000 units, 0.8 billion dollars. If the strike is prolonged, Hyundai's losses will exceed 1 billion dollars. The Hyundai Unions this year are asking for an increase in the basic salary of 150 dollars, a payment of 30 percent of last year's bonus, and an agreement on employment security. Therefore, the open empirical question is whether labor unions influence firm's CSR activity positively or negatively.

This paper has several advantages over the numerous labor union studies in the U.S. First, Korea has unique firm-year labor union data available and, thus, our more accurate and valuable labor union data uses comprehensive Korean firm-year hand-collected data. Second, we use firm-year labor union existence and labor unionization rates as proxies for the labor union influence on a firm. Finally, labor unions play significant roles as non-financial stakeholders in Korea [17,22,24]. In Korea, with their proud tradition of fierce protests heading back to the resistance against the military dictatorships of the 1970s and 1980s, labor unions remain somehow radical to firms.

As previously mentioned, we use two proxies to measure labor union influence towards firms: labor union existence and labor unionization rates. Using 675 firm-year observations for 2005-2008, we suggest labor union existence and the labor unionization rate are negatively associated with the level of CSR activity. Additionally, this negative association is more pronounced in non-owner manager firms. Our empirical results are consistent with those of quintile regression analysis. Following Hirch [23], labor unions' rent-seeking behavior could affect managers' CSR decision behavior. We can thus conjecture that labor unions allure managers to decrease CSR activity to higher short-term earnings to maximize wage premiums and most non-owner manager agree with labor unions because non-owner managers' incentive system in Korea is mostly based on short-term earnings. Further, endogeneity might be one of the important potential concerns in our study. To this end, we conduct a two-stage least squares (2SLS) regression using an instrumental variables approach, which yields similar results to our main results. For robustness testing, we conduct Heckman two-step regressions, and our empirical results are consistent with the main results. Therefore, the ordinary least squares (OLS) regression results are valid considering endogeneity concerns. 
This paper also adds to the sustainability literature. First, to the best of our knowledge, this is the first empirical attempt to show the direct association between firm-year-level labor union influence and the level of CSR activity, using owner and non-owner manager groups, while prior CSR papers focused on CSR with ownership structure or board composition. As such, this paper extends this literature stream by focusing on labor union influence on CSR. So, this paper might be the first relative empirical study to show labor union influence and firms' CSR activity in the firm-year-level context. Further, this influence has effects on the owner and non-owner manager groups.

Second, this paper has the advantage of using a firm-year labor union influence proxy. U.S. labor union data contains only industry-level data [20], in contrast to this study, which can provide more valid empirical results using the firm-year labor union proxy. Firm-level labor union data are critical to our research question because CSR activity could be accomplished at the firm level rather than industry level. Moreover, firms' CSR activity and labor unions' effects on CSR activity are not homogeneous across firms in the same industry but unique to each firm.

Third, extending labor union-related studies, this paper shows that labor unions could affect firms' CSR activity. Further, labor unions' collective activities are interesting to study because they differ from the direct intervention approach (e.g., strikes, political lobbying), while other governance structures, such as boards or institutional investors, do not. Additionally, this paper differs from and complements recent prior studies on the impact of labor unions on real EM [17] or investment efficiency [24] by focusing on sustainability issues with CSR activity. The remainder of the paper proceeds as follows. Section 2 summarizes the prior research and develops the research hypotheses. Section 3 describes the sample and presents the research design. Section 4 reports the results of the main analysis on the impact of the labor union on the extent of CSR and the cross-sectional analyses. Section 5 concludes the paper.

\section{Literature Review and Hypotheses Development}

\subsection{Labor Unions}

Previous research related to labor unions focused primarily on labor union influence on firm productivity and wage levels. The relationship between labor unions and firms is described as cooperative in terms of production but conflicting in terms of performance allocation. For example, to maximize profits, managers try to soften the supply of labor such as employment and dismissal and avoid rising wages, while labor unions increase their bargaining power towards improving working conditions and raising wages to increase the interests of workers. In other words, labor unions and corporations are related to the survival of enterprises and their future growth and development. However, even if the interests of the union have a direct relationship with wages, the wage in the enterprise is a cost and can thus have a conflicting relationship with the union. Previous work on labor unions and firm performance has found that labor unions have a weak positive role, limited influence, and a negative impact on profit.

As a result of analyzing the effects of the existence of labor unions on corporate performance and insolvency, Karier [25] pointed out that the higher the union organization rate in the industries with relatively high economic concentration, the higher the union wages and lower the profit are. It is possible that labor unions will promote corporate insolvency. Ruback and Zimmerman [26] analyzed the excess returns on the creation of labor unions for 253 companies listed on the NYSE from 1962 to 1980 and found that the creation of labor unions resulted, on average, in a decline in firm value. Lewis [27] argued unions raise wages by around 10-20\%. Further, Hirsch [23] argued that the excessive demand for short-term wages by labor unions hinders the future investment of companies, making it difficult to survive. Connolly et al. [28] noted unions reduce profitability by restricting R\&D investments and negatively impact growth. Overall, Hirsch [23] and Connolly et al. [28] interpret labor union rent-seeking behavior as a bad for the firm' long-term performance. 
On the other hand, if ownership and management are separate, the owner (shareholder) of the enterprise establishes a governance that can effectively monitor the manager to reduce agency cost. In this sense, Jensen and Meckling [29] provided examples of various corporate governance mechanisms used to present and mitigate the agency costs that can arise between owners (shareholders) and agency managers. Since unions composed of workers are in charge of actual work in the field and are directly involved in the generation and recognition of revenues and costs, the performance of a company can be observed more directly than by monitoring other organizations. As an insider, the labor union has a relative advantage over outsiders in its accessibility to information, it can effectively monitor managers. Additionally, there is a possibility that shareholders and interests are consistent with the future existence and long-term performance of the company and the labor union can voluntarily monitor the management as an incentive to monitor the manager's wage minimization. Schwab and Tomas [30] argued that workers directly supervise managers as insiders of the enterprise and, thus, play a role in recognizing and monitoring corporate policies and future plans sooner than shareholders. Chyz et al. [13] showed that tax avoidance has a negative relationship with unions, decreasing after unionization. They also argued unions play a positive monitoring role for the company. However, Chen et al. [12] studied whether unions influence the cost of firms' capital and found the cost of capital is significantly higher for firms engaged in unionized industries. Moreover, the union premium is stronger when the union faces a more favorable bargaining environment. The union also has a positive relationship with various operational leverage measures. These findings suggest unions increase the costs of equity by reducing the operational flexibility of an enterprise. Bradley et al. [16] examined the impact of unionization on the innovation activities of firms, finding the number of patents and citations decreased dramatically after firms formed unions, which also reduced the cost of $R \& D$ and lowered productivity. Therefore, unionization hinders innovation. Specifically, Chun and Shin [17] also showed, using Korean labor union data, that labor unions collude with managers and even promote real earnings management. Unionization may thus create misaligned incentives among employees and impede firm innovation.

\subsection{Corporate Social Responsibility}

Aguilera et al. [31] argue that firms are pressured to participate in CSR by various actors driven by instrumental, relational, and moral motives by the multiple needs theory. Several previous studies suggested CSR has a positive effect on corporate performance, and some studies even implied that CSR has negative or neutral effects on corporate performance. For instance, Carroll [1] defined CSR as corporate integrated responsibilities encompassing the economic, legal, ethical, and discretionary expectations the society has of organizations. From a stakeholder's theory perspective, CSR can generate sustained value depending on its relationship with various stakeholders [32]. Further, CSR is regarded as a pertinent firm strategy to enhance consumer perception of product quality and provides the opportunity for a company to give a premium to its products and services [2]. Additionally, CSR lowers cost of capital costs [3,4].

Particularly, Ghoul et al. [4] conducted an empirical analysis on the effects of CSR activities on the cost of equity of U.S. firms, showing that firms with high CSR have lower capital costs. Feng et al. [33] showed that short- and long-term economic performance is positively affected by CSR, which leads to sustainable financial development. Therefore, CSR-related studies suggest CSR activity could be a firms' sustainable determinant of survival in the near future [5,33]. However, since different parties may have different objectives and decision-making horizons, it is worthwhile to study the relationships between the different types of stakeholders and firms' social performance. At the same time, other studies emphasized the role of organizational factors such as slack resources [6] and firm size [5]. Waddock and Graves [6] suggested the good economic performance of an enterprise could potentially enable the use of spare resources, thereby allowing investment opportunities in social performance areas, such as donations, volunteering, and environmental protection. Additionally, prior papers investigate the effects of managerial ownership [7], foreign ownership [8], institutional 
ownership [9], and board structure [7] on CSR. However, there are relatively scarce studies on labor unions and CSR. Studies on unions and CSR are mostly theoretical studies and argue that the role of labor unions in CSR is important. Matten and Moon [34] deal with a conceptual framework for understanding $C S R$, and suggest that labor unions contribute to 'implicit' $C S R$, which is functionally equivalent to 'explicit' voluntary CSR engagement. Campbell [35] suggests that firms are more likely to act in a socially responsible manner when engaged in institutionalized dialogue with labor unions, employees, community groups, investors and other stakeholders. Meanwhile, Porter, Michael and Mark Kramer [36] argued for the importance of Creating Shared Value (CSV) beyond the CSR approach. CSV allows companies to leverage their skills and resources, and it provides opportunities for social progress in ways that cannot be matched. Porter, Michael and Mark Kramer [36] expect that if labor unions focus more on CSV, CSV will spread more quickly. In an empirical study on unions and CSR, Kinderman and Lutter [37] analyzed the growth of CSR in OECD countries and found that unions were positive for CSR activity and that some unions and companies welcomed CSR. On the other hand, wage bargaining centralization reduces a country's CSR activity. Dawkins [38] showed that union social responsibility has a positive relationship with union job satisfaction, and that union social responsibility can increase union cohesion and inform union strategy.

\subsection{Hypotheses Development}

This study conducts an empirical analysis about the effects of labor union influence on firms' CSR activity. As noted in the literature review, there are relatively few studies regarding the direct relationship between labor unions and CSR activity. However, labor unions are an important non-stakeholder group because, unlike shareholders and institutional owners who can reduce the risk by holding a diversified portfolio, employees are unlikely to be able to diversify their earnings from the firm. However, Amihud and Lev [39] suggested "human capital is not readily diversified".

In this context, prior studies examined the monitoring role of a labor union as part of the non-stakeholder group, the role of a corporate governance device $[13,24,29,30]$. However, other studies documented that labor unions play a negative role in terms of rent-seeking behavior for the firm (i.e., labor unions make wages stickier and layoffs costlier) [15-17]. Additionally, although labor unions have cooperative relationships with business managers in production, they might have opposite relationships in terms of performance allocation. Labor unions have a propensity to avoid risky investments [12,28], with wage increase incentives to maximize union profit [23,27]. Therefore, the open empirical question is whether labor unions influence firms' CSR activity. This is a relatively unexplored area in the literature and has a direct effect on the CSR literature.

As previously described, there have been no consistent, positive, or negative empirical results regarding labor union influence on firms' $C S R$ activity. Ex-ante, there would be a positive association between labor union influence and CSR if labor unions agree with managers' strategy to conduct CSR expenditure for the firm's sustainable growth and sacrifice short-term earnings. Conversely, there would be the negative association between labor union influence and CSR if labor unions disagree with a strategy to use CSR expenditure because labor unions seek to pursue short-term earnings as rent seeking behavior. In this context, labor unions try to determine managers to decrease CSR-related expenditure to obtain higher short-term reported earnings for a favorable wage negotiation process. Therefore, an empirical study on this subject may be a challenging task, with no specific correlational direction predictable. Based on the above discussion, this study empirically analyzes the labor union influence and CSR activities of Korean firms with the following null hypothesis that has no predictable direction of positive or negative correlation (Figure 1). As such, our first hypothesis is as follows:

Hypothesis 1. Labor union influence (labor union existence, labor unionization ratio) is associated with the CSR level. 
Further, we divide our sample into two groups: owner and non-owner managers. According to Jensen and Meckling [29], when ownership and management are separated, it is reported that the increase of managerial ownership increases the incentive to own the company and consequently reduces the agency's agent cost. Salancik \& Pfeffer [40] demonstrated that the lower the performance of professional managers in their studies, the shorter the term of their tenure. Given these high occupational risks, non-owner (professional) managers are expected to make decisions that will increase their employability not to leave their job. We posit that non-owner managers try to cut CSR expenditure to boost reported earnings according to the labor union influence. On the other hand, owner managers hardly cut CSR expenditure even when labor unions strongly influence CSR activity. Therefore, we posit that labor union influence on CSR activity is more pronounced for non-owner manager groups. On average, non-owner managers' incentive system is more tied to firms' reported earnings, making them more likely to cooperate with the labor union. As such, on average, non-owner manager firms might cut CSR activity to boost reported earnings by labor union influence, which means we expect the negative association between labor union influence and CSR activity to be more pronounced in the non-owner manager sample (Figure 1). Thus, our second hypothesis is as follows:

Hypothesis 2. Ceteris paribus, the negative association between labor union influence and CSR level is more pronounced in non-owner manager firms.

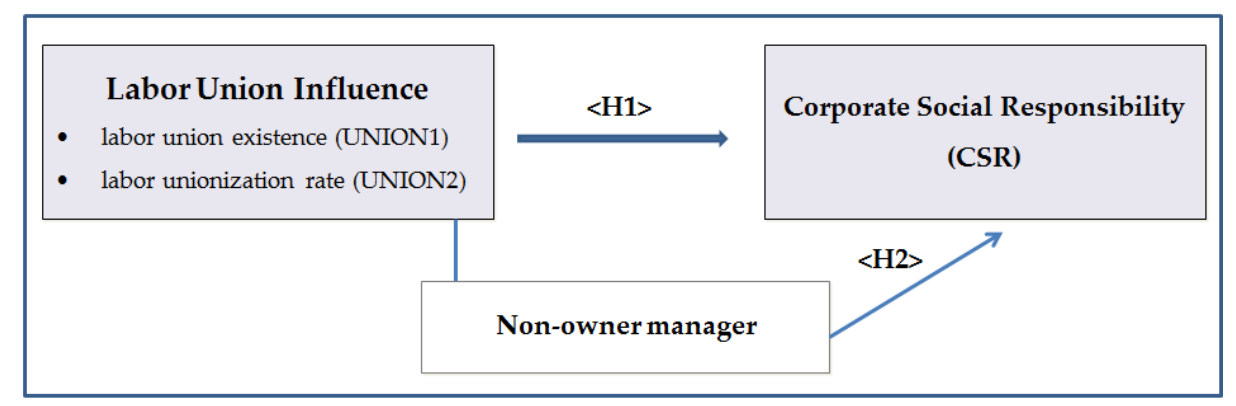

Figure 1. Labor Union and Corporate Social Responsibility.

\section{Research Methodology}

\subsection{CSR Activity Measures}

Following prior studies, this study utilizes the KEJI index created and measured by KEJI as a proxy for CSR activities. The KEJI index is comprised of seven key assessment areas, 49 evaluation indicators, and four other indicators. The total score of the seven key assessment areas is 75 : integrity (20), fairness (11), contribution to social service (7), consumer protection satisfaction (7), environment protection satisfaction (10), employee satisfaction (10), and contribution to economic development of Korea (10). The KEJI index was used as a proxy of the social impact of companies because it measures the level of ethical operation of the firms and their social responsibility in the most comprehensive and inclusive manner. Furthermore, it obtained a considerable level of reliability and stability of assessment over a period of more than 10 years. The KEJI uses criteria that are most similar to those of ISO 26000, the international standard for CSR. Additionally, the use of the KEJI index in this study is significant because it allows us to compare the results of CSR activities and market responses with those of the literature. Lastly, the use of the KEJI index, which is based on data collected from an impartial civil organization, allows this study an objective analysis [24]. Specifically, this study performs an empirical analysis by using the sum of KEJI index scores as a proxy of a company's CSR activities. 


\subsection{Empirical Model}

We test the hypotheses using Equation (1) below. The dependent variable of Equation (1) is the proxy of a company's CSR activities and the independent variable is labor union existence and labor unionization ratio, which are proxies for labor union influence $[17,24]$. We performed multiple regression analyses on Equation (1).

$$
\begin{gathered}
\operatorname{CSR}_{i, \mathrm{t}}=\beta_{0}+\beta_{1} \mathrm{UNION}_{(\mathrm{UNION} 2)_{i, \mathrm{t}}+\beta_{2} \mathrm{LNSIZE}_{i, \mathrm{t}}+\beta_{3} L E V_{i, \mathrm{t}}+\beta_{4} R O A_{i, \mathrm{t}}+\beta_{5} M B_{i, \mathrm{t}}} \\
+\beta_{6} \text { FOR }_{i, \mathrm{t}}+\text { Industry } \mathcal{E} \text { Year Fixed Effects }+\varepsilon,
\end{gathered}
$$

where CSR is a ratio calculated by dividing the KEJI index by 75. UNION1 is an indicator variable equal to 1 if the firm has a labor union, and 0 otherwise. UNION2 is the labor unionization rate calculated as the union membership number divided by the total number of employees. LNSIZE is the natural log of total assets. To control for bias in the distribution of total assets, the natural log of the same variable (LNSIZE) was used as a substitute value in the following empirical analysis. $L E V$ is calculated as total debts divided by total assets. $R O A$ is calculated as net income divided by total assets. $M B$ is the market-to-book ratio, a ratio of market value to book value of equity. FOR is the foreign ownership ratio.

This study considers the control variables in the model to analyze the relationship between labor union influence and CSR activities. The selection of control variables is based on previous studies. Here, the selected control variables are LNSIZE (firm size), LEV (debt ratio), ROA (return on assets), $M B$ (market value ratio to book value), and FOR (foreign ownership rate). LNSIZE serves as a substitute variable for the variables that are omitted from the model equation [8,41]. For firm size, it is expected that a large firm will positively focus on CSR activities and positive correlation is expected. The debt ratio $(L E V)$ is called financial leverage because it provides information on the ability of a company to repay its debt and the inherent risks of the company. In previous research, it was suggested that financial leverage is related to CSR. Waddock and Graves [6] used debt ratios to control corporate risk, while verifying the relationship between CSR and financial performance. As the assets profit rate $(R O A)$ indicates the profitability of the company, it predicts a positive correlation [41,42] because it is determined that a profitable company has resources to actively carry out CSR activities. A company with growth potential can be more active in CSR activities, which predicts a positive correlation between the market value ratio to book value $(M B)$ and CSR activities [41]. Previous studies have shown a positive relationship between CSR and foreign ownership [43]. The higher the foreign ownership (FOR), the more CSR is expected to increase. Because we use a panel data sample, in addition to the variables for industry and year, we performed a fixed effect analysis. To mitigate the influence of extreme values, all continuous variables are winsorized at the $1 \%$ and $99 \%$ levels.

To mitigate the endogeneity problem of labor union influence and CSR activity, this paper performs 2SLS regression analysis. The equation is as follows:

$$
\begin{gathered}
\text { First stage: UNION1 }(\text { UNION2 })_{i, \mathrm{t}}=\beta_{0}+\beta_{1} \text { WORKAGE }_{i, \mathrm{t}}+\beta_{2} \mathrm{LNSIZE}_{i, \mathrm{t}}+\beta_{3} L E V_{i, \mathrm{t}}+ \\
\beta_{4} R O A_{i, \mathrm{t}}+\beta_{5} M B_{i, \mathrm{t}}+\beta_{6} F O R_{i, \mathrm{t}}+\varepsilon,
\end{gathered}
$$

where WORKAGE is the logarithm value of the average tenure of workers, following Chen et al. [11].

$$
\begin{aligned}
& \text { Second stage: } \left.C S R_{i, \mathrm{t}}=\beta_{0}+\beta_{1} \text { Fitted value of UNION1(UNION2) }\right)_{i, \mathrm{t}}+\beta_{2} L N S I Z E_{i, \mathrm{t}}+ \\
& \quad \beta_{3} L E V_{i, \mathrm{t}}+\beta_{4} R O A_{i, \mathrm{t}}+\beta_{5} M B_{i, \mathrm{t}}+\beta_{6} \text { FOR }_{i, \mathrm{t}}+\text { Industry } \mathcal{E} \text { Year Fixed Effects }+\varepsilon
\end{aligned}
$$

According to labor union literature, the average years of tenure of workers may be related to the firm-year labor unionization level. Since senior workers have a relatively strong job attachment and low mobility, their expected benefits from labor unionization are likely to be high [12]. Therefore, we expect a positive relation between WORKAGE and UNION1 as well as UNION2 in Equation (2). Then, we calculate the fitted value of UNION1 and UNION2 and apply this value as the predicted value for Equation (3). 


\subsection{Sample}

Our empirical analysis is based on a sample of Korean firms listed on KOSPI from 2005 to 2008. We conduct an empirical analysis on the periods of disclosure of social responsibility activity scores (from 2005) and labor union participation rates for all publicly listed companies during the period of mandatory listing (until 2008). In our sample period, all listed firms were required to report the numbers of union members and of total employees in the electronic corporate filing services of the Financial Supervisory Services (FSS, equivalent to the SEC in the U.S.) until 2008. We hand-collected the data to construct firm-year level unionization influence (labor union existence, the ratio of union to total employees). In Korea, the existence of a labor union and labor unionization rate were only disclosed until 2008, after which Korean firms did not mandatorily or voluntarily disclose these figures in electronic corporate filings. However, labor union data in Korea has a unique firm-year labor unionization rate, as opposed to industry labor unionization data in the U.S. (We performed firm-level clustering regression to reduce the heteroscedasticity of panel data) [44]. Two-stage least square regression and Heckman two-step analysis were also performed to reduce the problem of endogeneity.) So, we use Korean firm-year labor unionization ratio to capture the firm-level labor union influence toward the firm. We admit that labor union data is available until year 2008; however, most of the labor union related literature shows the same data problem. We used the SAS 9.4 software to construct the data and used STATA11 program for the empirical analysis and its output. We selected companies that satisfy the following criteria: (1) firms with financial statement data available from Kis-value; (2) firms with KEJI index score and labor union information available from the FSS; (3) fiscal year ending 31 December; and (4) firms in non-financial industries. This process yielded a final sample of 675 annual firm-year observations for companies listed on the KOSPI between 2005 and 2008.

\section{Empirical Results}

\subsection{Descriptive Statistics}

Panel A of Table 1 shows the descriptive statistics of the main variables regarding CSR firms, labor union influence, and control variables. The mean (standard deviation) of CSR is 47.429 (2.468) and the median is 45.380 . The mean (median) of labor unionization existence (UNION1) is 0.714 (1) and that of the labor unionization ratio (UNION2) is 0.300 (0.267). As such, labor unionization existence and the labor union ratio are similar to the results of extant studies [21]. All other control variables, namely LNSIZE, LEV , ROA, MB, FOR, are similar to those in prior studies [8,33].

Panel B of Table 1 compares firm characteristics across high versus low unionization sub-samples. We divided the sample into two groups by the sample median of labor unionization rates. This table shows that firms with a high unionization rate have fewer CSR activities than those with low unionization. On the other hand, LNSIZE and LEV are significantly higher and MB is significantly lower for a high unionization rate. However, these univariate comparisons do not control for other factors affecting CSR activities.

Table 1. Descriptive statistics.

\begin{tabular}{ccccccc}
\hline \multicolumn{7}{c}{ Panel A. Summary statistics } \\
\hline Variables & $\boldsymbol{N}$ & Mean & Std. dev. & 25th & Median & 75th \\
\hline KEJI index score & 675 & 47.429 & 2.468 & 45.380 & 47.060 & 49.030 \\
CSR & 675 & 0.632 & 0.032 & 0.605 & 0.627 & 0.653 \\
UNION1 & 675 & 0.714 & 0.452 & 0 & 1 & 1 \\
UNION2 & 675 & 0.300 & 0.277 & 0 & 0.267 & 0.559 \\
LNSIZE & 675 & 26.989 & 1.571 & 25.754 & 26.530 & 27.768 \\
LEV & 675 & 0.389 & 0.169 & 0.249 & 0.384 & 0.520 \\
ROA & 675 & 0.070 & 0.054 & 0.032 & 0.061 & 0.099. \\
MB & 675 & 1.295 & 0.978 & 0.631 & 0.982 & 1.609 \\
FOR & 675 & 0.178 & 0.175 & 0.031 & 0.113 & 0.286 \\
\hline
\end{tabular}


Table 1. Cont.

\begin{tabular}{clcccc}
\hline \multicolumn{7}{c}{ Panel B. High vs. Low Union Samples } \\
\hline High Unionization & \multicolumn{2}{c}{ Low Unionization } & Difference \\
\hline Variables & Mean & SD & Mean & SD & $p$-Value \\
\hline UNION2 & 0.548 & 0.008 & 0.052 & 0.004 & 0.00 \\
CSR & 0.628 & 0.001 & 0.635 & 0.001 & 0.00 \\
LNSIZE & 27.206 & 0.088 & 26.590 & 0.080 & 0.00 \\
LEV & 0.407 & 0.009 & 0.371 & 0.009 & 0.00 \\
ROA & 0.069 & 0.003 & 0.071 & 0.002 & 0.71 \\
MB & 1.183 & 0.047 & 1.408 & 0.058 & 0.00 \\
FOR & 0.181 & 0.009 & 0.175 & 0.009 & 0.68 \\
\hline
\end{tabular}

\subsection{Univariate Analysis}

Table 2 reports the Pearson correlation coefficients among the main variables. The labor unionization ratio (UNION2), which is the interest variable of this study, shows a significant negative correlation with CSR. On the other hand, the labor unionization existence (UNION1) shows a positive but insignificant correlation with CSR. However, the implication of the univariate result is limited. Therefore, we perform multivariate regression analysis to examine the overall association between labor union influence and CSR with control variables.

Table 2. Univariate correlations among key variables.

\begin{tabular}{|c|c|c|c|c|c|c|c|}
\hline Variables & CSR & UNION1 & UNION2 & LNSIZE & $L E V$ & $R O A$ & $M B$ \\
\hline UNION1 & $\begin{array}{c}0.004 \\
(0.913)\end{array}$ & & & & & & \\
\hline UNION2 & $\begin{array}{c}-0.073 \\
(0.054)\end{array}$ & $\begin{array}{l}0.680 \\
(0.00)\end{array}$ & & & & & \\
\hline LNSIZE & $\begin{array}{c}0.348 \\
(0.000)\end{array}$ & $\begin{array}{c}0.253 \\
(0.693)\end{array}$ & $\begin{array}{c}0.248 \\
(0.928)\end{array}$ & & & & \\
\hline$L E V$ & $\begin{array}{l}-0.075 \\
(0.049)\end{array}$ & $\begin{array}{c}0.152 \\
(0.000)\end{array}$ & $\begin{array}{c}0.141 \\
(0.000)\end{array}$ & $\begin{array}{c}0.351 \\
(0.000)\end{array}$ & & & \\
\hline$R O A$ & $\begin{array}{c}0.243 \\
(0.000)\end{array}$ & $\begin{array}{l}-0.047 \\
(0.222)\end{array}$ & $\begin{array}{c}0.004 \\
(0.901)\end{array}$ & $\begin{array}{c}0.118 \\
(0.002)\end{array}$ & $\begin{array}{l}-0.227 \\
(0.000)\end{array}$ & & \\
\hline$M B$ & $\begin{array}{c}0.323 \\
(0.000)\end{array}$ & $\begin{array}{c}0.050 \\
(0.188)\end{array}$ & $\begin{array}{l}-0.069 \\
(0.070)\end{array}$ & $\begin{array}{c}0.298 \\
(0.000)\end{array}$ & $\begin{array}{l}-0.177 \\
(0.000)\end{array}$ & $\begin{array}{c}0.369 \\
(0.000) \\
\end{array}$ & \\
\hline FOR & $\begin{array}{c}0.269 \\
(0.000)\end{array}$ & $\begin{array}{c}0.095 \\
(0.013)\end{array}$ & $\begin{array}{c}0.061 \\
(0.113)\end{array}$ & $\begin{array}{c}0.464 \\
(0.000)\end{array}$ & $\begin{array}{l}-0.049 \\
(0.198)\end{array}$ & $\begin{array}{c}0.297 \\
(0.000)\end{array}$ & $\begin{array}{c}0.314 \\
(0.000)\end{array}$ \\
\hline
\end{tabular}

\subsection{Multivariate Analysis}

We first analyze the impact of labor unionization existence and the labor unionization ratio on firms' CSR activity. Our sample is a form of unbalanced panel data. In addition to the variables of the individual firms already included, we conducted industry- and year-fixed effect analyses to control the attributes of industry and year effectively. Additionally, we used the firm-level cluster standard errors regression analysis according to Peterson [44] to control the distortion of the regression results from the characteristics of the panel data.

Table 3 shows the effect of labor union influence on CSR activity. In models (1) and (2), labor union existence (UNION1) has a statistically and significantly negative association with $\operatorname{CSR}(t$-value $=-2.495)$ and the labor unionization ratio (UNION2) is statistically and significantly negatively associated with CSR ( $t$-value $=-3.757)$. In addition, UNION1 and UNION2 in models (3) and (4) of the cluster analysis are statistically and significantly negatively associated with 
$\operatorname{CSR}(t$-value $=-1.781,-2.975)$. These results suggest firms decrease CSR activity when the influence of labor unions increases. We find evidence that the managers of firms that have labor unions and higher labor unionization rates are more likely to decrease CSR, as the empirical results suggest labor union existence and the labor unionization rate are negatively associated with the CSR level. Therefore, labor unions' rent-seeking behavior could directly affect managers' behavior. We can thus conjecture that labor unions determine managers to decrease CSR activity to obtain higher short-term profit to maximize labor union' wage when managers agree with the labor union. This paper's main results thus support the negative role of labor unions $[12,16]$.

Table 3. Labor union influence and CSR.

\begin{tabular}{ccccc}
\hline Variables & $\mathbf{( 1 )}$ & $\mathbf{( 2 )}$ & $\mathbf{( 3 )}$ & $\mathbf{( 4 )}$ \\
\hline UNION1 & $-0.006^{* *}$ & & $-0.006^{*}$ & \\
& $(-2.495)$ & & $(-1.781)$ & \\
\hline UNION2 & & $-0.016^{* * *}$ & & $-0.016^{* * *}$ \\
& & $(-3.757)$ & & $(-2.975)$ \\
\hline \multirow{2}{*}{ LNSIZE } & $0.007^{* * *}$ & $0.008^{* * *}$ & $0.007^{* * *}$ & $0.008^{* * *}$ \\
& $(8.098)$ & $(8.329)$ & $(6.716)$ & $(7.354)$ \\
\hline \multirow{2}{*}{ MB } & $0.007^{* * * *}$ & $0.006^{* * *}$ & $0.007^{* * *}$ & $0.006^{* * *}$ \\
& $(5.039)$ & $(4.506)$ & $(4.847)$ & $(4.155)$ \\
\hline \multirow{2}{*}{ LEV } & $-0.038^{* * *}$ & $-0.036^{* * *}$ & $-0.038^{* * * *}$ & $-0.036^{* * *}$ \\
& $(-4.664)$ & $(-4.406)$ & $(-3.543)$ & $(-3.394)$ \\
\hline \multirow{2}{*}{ FOA } & 0.015 & 0.025 & 0.015 & 0.025 \\
& $(0.642)$ & $(1.075)$ & $(0.541)$ & $(0.880)$ \\
\hline Constant & 0.008 & 0.008 & 0.008 & 0.008 \\
& $(1.083)$ & $(1.083)$ & $(0.918)$ & $(0.933)$ \\
\hline Year fixed effects & $0.489^{* * *}$ & $0.486^{* * *}$ & $0.489 * * *$ & $0.486^{* * *}$ \\
Industry fixed effects & $(28.834)$ & $(28.751)$ & $(23.727)$ & $(24.642)$ \\
Firm cluster & Yes & Yes & Yes & Yes \\
Observations & No & Yes & Yes & Yes \\
R-squared & 675 & 675 & Yes & Yes \\
\hline$* * * * * *$ indicate respectively significance at the $1 \%, 5 \%$, and $10 \%$ levels or better. \\
\hline
\end{tabular}

To test the second hypothesis, we divided our sample into two groups: owner and non-owner managers (If the CEO is the largest shareholder, the firm belongs to the owner manager sample). As discussed in the prior section, the influence on CSR activity might be different for non-owner and owner managers. Table 4 shows the correlation between labor union existence and the labor unionization rate with CSR activity in both groups. A negative association is only seen for the non-owner manager sample. Therefore, labor union existence (UNION1) and the labor unionization rate (UNION2) are statistically and significantly negatively associated with CSR activity in non-owner manager groups at the $1 \%$ level. As expected, non-owner managers' incentive system is more related to short-term reported earnings and non-owner managers cooperate with labor unions to obtain higher reported earnings by sacrificing CSR expenditure. As such, non-owner managers collude with labor unions to obtain higher reported earnings because they need to show business performance to shareholders or creditors. Overall, our results suggest the second hypothesis is supported in that the negative association between labor union and CSR activity is more pronounced in non-owner manager firms. 
Table 4. Labor union influence and CSR (owner vs. non-owner managers).

\begin{tabular}{|c|c|c|c|c|}
\hline \multicolumn{5}{|c|}{ Panel A: Owner Manager } \\
\hline Variables & (1) & (2) & (3) & (4) \\
\hline UNION1 & $\begin{array}{c}0.001 \\
(0.422)\end{array}$ & & $\begin{array}{c}0.001 \\
(0.271)\end{array}$ & \\
\hline UNION2 & & $\begin{array}{c}-0.011 \\
(-1.632)\end{array}$ & & $\begin{array}{c}-0.011 \\
(-1.469)\end{array}$ \\
\hline LNSIZE & $\begin{array}{c}0.006^{* * *} \\
(3.558)\end{array}$ & $\begin{array}{c}0.007^{* * * *} \\
(3.830)\end{array}$ & $\begin{array}{c}0.006 \text { *** } \\
(2.997)\end{array}$ & $\begin{array}{c}0.007^{* * *} \\
(3.201)\end{array}$ \\
\hline$M B$ & $\begin{array}{l}0.006^{* *} \\
(2.225)\end{array}$ & $\begin{array}{l}0.005 * \\
(1.784)\end{array}$ & $\begin{array}{l}0.006^{* *} \\
(2.324)\end{array}$ & $\begin{array}{l}0.005 * \\
(1.834)\end{array}$ \\
\hline$L E V$ & $\begin{array}{c}-0.045^{* * *} \\
(-3.654)\end{array}$ & $\begin{array}{c}-0.039 * * * \\
(-3.120)\end{array}$ & $\begin{array}{l}-0.045^{* *} \\
(-2.405)\end{array}$ & $\begin{array}{l}-0.039 * * \\
(-2.096)\end{array}$ \\
\hline$R O A$ & $\begin{array}{c}0.013 \\
(0.397)\end{array}$ & $\begin{array}{c}0.014 \\
(0.424)\end{array}$ & $\begin{array}{c}0.013 \\
(0.321)\end{array}$ & $\begin{array}{c}0.014 \\
(0.320)\end{array}$ \\
\hline FOR & $\begin{array}{c}0.001 \\
(0.058)\end{array}$ & $\begin{array}{c}0.000 \\
(0.014)\end{array}$ & $\begin{array}{c}0.001 \\
(0.051)\end{array}$ & $\begin{array}{c}0.000 \\
(0.012)\end{array}$ \\
\hline Constant & $\begin{array}{l}0.504^{* * *} \\
(15.593)\end{array}$ & $\begin{array}{l}0.501^{* * *} \\
(15.621)\end{array}$ & $\begin{array}{l}0.504^{* * *} \\
(14.153)\end{array}$ & $\begin{array}{l}0.501 * * * \\
(14.189)\end{array}$ \\
\hline Year fixed effects & Yes & Yes & Yes & Yes \\
\hline Industry fixed effects & Yes & Yes & Yes & Yes \\
\hline Firm cluster & No & No & Yes & Yes \\
\hline Observations & 304 & 304 & 304 & 304 \\
\hline$R$-squared & 0.319 & 0.325 & 0.319 & 0.325 \\
\hline \multicolumn{5}{|c|}{ Panel B: Non-Owner Manager } \\
\hline Variables & (1) & (2) & (3) & (4) \\
\hline UNION1 & $\begin{array}{c}-0.015^{* * *} \\
(-3.722)\end{array}$ & & $\begin{array}{c}-0.015^{* * *} \\
(-3.558)\end{array}$ & \\
\hline UNION2 & & $\begin{array}{c}-0.025^{* * *} \\
(-4.157)\end{array}$ & & $\begin{array}{c}-0.025^{* * *} \\
(-3.610)\end{array}$ \\
\hline LNSIZE & $\begin{array}{c}0.007^{* * *} \\
(6.356)\end{array}$ & $\begin{array}{c}0.007^{* * *} \\
(6.341)\end{array}$ & $\begin{array}{c}0.007^{* * *} \\
(5.625)\end{array}$ & $\begin{array}{c}0.007^{* * *} \\
(6.007)\end{array}$ \\
\hline$M B$ & $\begin{array}{c}0.009^{* * *} \\
(5.012)\end{array}$ & $\begin{array}{c}0.008^{* * *} \\
(4.597)\end{array}$ & $\begin{array}{c}0.009 * * * \\
(5.280)\end{array}$ & $\begin{array}{c}0.008^{* * *} \\
(5.071)\end{array}$ \\
\hline$L E V$ & $\begin{array}{c}-0.040 * * * \\
(-3.589)\end{array}$ & $\begin{array}{c}-0.038^{* * *} \\
(-3.402)\end{array}$ & $\begin{array}{c}-0.040^{* * *} \\
(-3.481)\end{array}$ & $\begin{array}{c}-0.038 * * * \\
(-3.248)\end{array}$ \\
\hline$R O A$ & $\begin{array}{c}0.016 \\
(0.473) \\
\end{array}$ & $\begin{array}{c}0.037 \\
(1.127) \\
\end{array}$ & $\begin{array}{c}0.016 \\
(0.408) \\
\end{array}$ & $\begin{array}{c}0.037 \\
(0.994) \\
\end{array}$ \\
\hline FOR & $\begin{array}{c}0.013 \\
(1.357)\end{array}$ & $\begin{array}{c}0.011 \\
(1.139)\end{array}$ & $\begin{array}{c}0.013 \\
(1.094)\end{array}$ & $\begin{array}{c}0.011 \\
(0.957)\end{array}$ \\
\hline Constant & $\begin{array}{l}0.505^{* * *} \\
(23.845)\end{array}$ & $\begin{array}{l}0.501 * * * \\
(23.747)\end{array}$ & $\begin{array}{l}0.505 * * * \\
(19.473)\end{array}$ & $\begin{array}{l}0.501 * * * \\
(20.571)\end{array}$ \\
\hline Year fixed effects & Yes & Yes & Yes & Yes \\
\hline Industry fixed effects & Yes & Yes & Yes & Yes \\
\hline Firm cluster & No & No & Yes & Yes \\
\hline Observations & 371 & 371 & 371 & 371 \\
\hline$R$-squared & 0.424 & 0.429 & 0.424 & 0.429 \\
\hline
\end{tabular}

$* * *, * *, *$ indicate respectively the significance level at the $1 \%, 5 \%$ and $10 \%$ level or better. 


\subsection{Robustness Analysis}

Table 5 shows the results of quantile regression. Quantile regression is a type of regression analysis used in statistics and econometrics. Whereas the method of least squares results in estimates of the conditional mean of the response variable, given certain values of the predictor variables, quantile regression aims at estimating either the conditional median or other quantiles of the response variable. The quantile regression analysis method for CSR is discussed in previous studies (e.g., [45]). Table 5 shows the results of entire sample at five quantiles. First, UNION2 (labor unionization ratio) is consistently showing a negative correlation at a significant level in each quintile except for the $10 \%$ quantile: at the $10 \%$ quantile it is $-0.002(t=-0.379)$, at $25 \%-0.010(t=-2.513)$, at $50 \%-0.017$ $(t=-4.318)$, at $75 \%-0.018(t=3.678)$, and at $90 \%-0.020(t=-2.549)$. These results indicate the labor unionization ratio generally has a negative relationship with CSR, which is consistent with the results in Table 3. Therefore, Table 5 shows that the main results of this study are robust even if we perform quintile regression analysis.

Table 5. Robustness test: Quintile regression analysis.

\begin{tabular}{|c|c|c|c|c|c|}
\hline \multirow[b]{2}{*}{ Variables } & \multicolumn{5}{|c|}{ CSR Quintile Regression } \\
\hline & Q10 & Q25 & Q50 & Q75 & Q90 \\
\hline UNION2 & $\begin{array}{c}-0.002 \\
(-0.379)\end{array}$ & $\begin{array}{c}-0.010 * * \\
(-2.513)\end{array}$ & $\begin{array}{c}-0.017^{* * *} \\
(-4.318)\end{array}$ & $\begin{array}{c}-0.018^{* * *} \\
(-3.678)\end{array}$ & $\begin{array}{c}-0.020 \text { ** } \\
(-2.549)\end{array}$ \\
\hline LNSIZE & $\begin{array}{l}0.003 * \\
(1.717)\end{array}$ & $\begin{array}{c}0.006^{* * *} \\
(5.529)\end{array}$ & $\begin{array}{c}0.008^{* * *} \\
(8.170)\end{array}$ & $\begin{array}{c}0.009 * * * \\
(6.924)\end{array}$ & $\begin{array}{c}0.008^{* * *} \\
(4.601)\end{array}$ \\
\hline$L E V$ & $\begin{array}{c}-0.012 \\
(-1.561)\end{array}$ & $\begin{array}{l}-0.025^{* *} \\
(-2.473)\end{array}$ & $\begin{array}{l}-0.020 * \\
(-1.899)\end{array}$ & $\begin{array}{c}-0.043^{* * *} \\
(-4.536)\end{array}$ & $\begin{array}{c}-0.070 \text { *** } \\
(-5.134)\end{array}$ \\
\hline$R O A$ & $\begin{array}{c}-0.012 \\
(-0.349)\end{array}$ & $\begin{array}{c}-0.017 \\
(-0.626)\end{array}$ & $\begin{array}{c}0.028 \\
(0.856)\end{array}$ & $\begin{array}{c}0.037 \\
(0.980)\end{array}$ & $\begin{array}{c}0.018 \\
(0.434)\end{array}$ \\
\hline$M B$ & $\begin{array}{c}0.006^{* * *} \\
(3.283)\end{array}$ & $\begin{array}{c}0.007^{* * *} \\
(5.542)\end{array}$ & $\begin{array}{c}0.004^{* * *} \\
(2.965)\end{array}$ & $\begin{array}{l}0.006 * * \\
(2.346)\end{array}$ & $\begin{array}{c}0.010^{* * *} \\
(5.806)\end{array}$ \\
\hline FOR & $\begin{array}{c}0.004 \\
(0.299) \\
\end{array}$ & $\begin{array}{c}0.009 \\
(0.974)\end{array}$ & $\begin{array}{c}0.015 \\
(1.634)\end{array}$ & $\begin{array}{c}0.002 \\
(0.295)\end{array}$ & $\begin{array}{c}-0.013 \\
(-0.927)\end{array}$ \\
\hline Constant & $\begin{array}{c}0.537^{* * *} \\
(16.075)\end{array}$ & $\begin{array}{l}0.491^{* * *} \\
(26.392)\end{array}$ & $\begin{array}{l}0.463 * * * \\
(27.833)\end{array}$ & $\begin{array}{l}0.477^{* * *} \\
(19.294)\end{array}$ & $\begin{array}{l}0.503 * * * \\
(14.629)\end{array}$ \\
\hline Industry fixed effect & yes & yes & yes & yes & yes \\
\hline Year fixed effect & yes & yes & yes & yes & yes \\
\hline Observations & 675 & 675 & 675 & 675 & 675 \\
\hline Pseudo $R^{2} R$ & 0.130 & 0.183 & 0.250 & 0.249 & 0.292 \\
\hline
\end{tabular}

Test of slope coefficient $(\mathrm{Q} 10=\mathrm{Q} 90): 10-90 \%$ quantiles; $F(1,644)=3.54 ;$ Prob. $>F=0.0604 ; * * *, * * *$ indicate respectively significance at the $1 \%, 5 \%$ and $10 \%$ levels or better.

On the other hand, in Table 2, the labor union influence has a significant correlation with LEV, $M B$, and FOR. This implies that labor union influence comprehensively considers the financial status and business performance of a company, as well as the endogenous variable induced by the financial condition and business performance of the company. As the endogenous variables have the potential of reverse causality, there is a possibility that for labor union influence on CSR, the characteristics of the firm expressed as CSR scores can also influence labor unions' influence.

We try to control for the possible endogeneity of union influence more formally using 2SLS regressions. The OLS regression might have potential endogeneity problems by reverse causality, which might affect the effects of labor union influence on CSR. The possible endogeneity problem is that labor union existence or the labor unionization ratio is already determined by a firms' CSR activity. Therefore, we need to perform 2SLS regressions to reduce the above reverse causality problem. In our context, good instruments are exogenous variables that are economically related to labor unionization 
influence but are uncorrelated with the error term of the second-stage regression relating the firm's level of CSR to unionization. To find such instruments, we consider the literature on labor union. For instance, Chen et al. [11] suggested the tenure of workers may be related to the unionization level. Since senior workers have a relatively strong job attachment and low mobility, their expected benefits from unionization are likely to be high [11]. Therefore, we expect a positive relation between WORKAGE and UNION1 as well as UNION2. Table 6 reports the 2SLS estimates of Equation (1), in which we treat UNION1 and UNION2 as endogenous variables that we instrument with WORKAGE. Panel A of Table 5 reports the first-stage regression results relating to UNION1 as well as UNION2 with WORKAGE and the exogenous variables of the model. As expected, the coefficient on WORKAGE is significantly positively associated with UNION1 at the 5\% level and with UNION2 at the $1 \%$ level. Panel B of Table 6 reports the coefficients from the second-stage regression of CSR on the value of UNION predicted in the first-stage regression and the corresponding exogenous control variables. Using the fitted value of the first-stage regression of UNION1 as well as UNION2, we repeat the analyses in Table 3 and report the results of the second stage in Table 6. The coefficient on the fitted value of labor union is still negative and significant for CSR. This indicates managers' general tendency towards CSR when labor unions are stronger, this is maintained even after controlling for the endogeneity of labor union strength.

Table 6. Robustness test: 2SLS regression.

\begin{tabular}{|c|c|c|}
\hline \multicolumn{3}{|c|}{ Panel A. First-Stage Regressions } \\
\hline & (1) & (2) \\
\hline Variables & UNION1 & UNION2 \\
\hline WORKAGE & $\begin{array}{c}0.006^{* *} \\
(2.033)\end{array}$ & $\begin{array}{c}0.010^{* * *} \\
(5.264)\end{array}$ \\
\hline LNSIZE & $\begin{array}{c}0.060^{* * *} \\
(4.252)\end{array}$ & $\begin{array}{c}0.035^{* * *} \\
(4.085)\end{array}$ \\
\hline$L E V$ & $\begin{array}{c}0.167 \\
(1.438) \\
\end{array}$ & $\begin{array}{c}0.178 * * \\
(2.574)\end{array}$ \\
\hline$R O A$ & $\begin{array}{l}-0.495 \\
(-1.384)\end{array}$ & $\begin{array}{l}0.374 \text { * } \\
(1.752)\end{array}$ \\
\hline$M B$ & $\begin{array}{c}-0.003 \\
(-0.168) \\
\end{array}$ & $\begin{array}{c}-0.050 * * * \\
(-4.214)\end{array}$ \\
\hline FOR & $\begin{array}{c}0.044 \\
(0.380)\end{array}$ & $\begin{array}{c}0.001 \\
(0.008)\end{array}$ \\
\hline Constant & $\begin{array}{c}-0.560 * * \\
(-2.226)\end{array}$ & $\begin{array}{c}-0.479 * * * \\
(-3.185)\end{array}$ \\
\hline Observations & 675 & 675 \\
\hline$R$-squared & 0.078 & 0.130 \\
\hline \multicolumn{3}{|c|}{ Panel B. Second Stage Regression: The Relation between CSR and Union Strength } \\
\hline \multirow[t]{2}{*}{ Dep. Var. } & \multicolumn{2}{|c|}{ CSR } \\
\hline & (1) & (2) \\
\hline Union & UNION1 & UNION2 \\
\hline Fitted value of union & $\begin{array}{l}-0.177^{* *} \\
(-2.236)\end{array}$ & $\begin{array}{l}-0.128 * * * \\
(-3.784)\end{array}$ \\
\hline Control variables & YES & YES \\
\hline Year fixed effects & YES & YES \\
\hline Industry fixed effects & YES & YES \\
\hline Observations & 675 & 675 \\
\hline
\end{tabular}


Until now, we examined the effects between the existence of labor unions and the labor union rate on CSR activities for the entire sample. Additionally, we examined the effects of the labor union rate on CSR activities for the sample with labor unions rather than the entire sample. Column 1 in Table 7 shows the OLS results for the labor union rate for the CSR of the sample with UNION1 (union existence) rather than the entire sample. That is, the sample with labor is used in Table 7 . The results of model 1 show that CSR decreases as the labor unionization rate (UNION2) increases, as shown in Table 3. So, the results of model 1 are also robust to the hypotheses of this study. However, because of the bias of sample selection when using only union firms, we conducted analysis using Heckman's [46] two-step analysis method. First, we analyzed the determinants of the presence of unions by using instrument variables. The second step consists of adding the inverse mills ratio (IMR), estimated in the first step analysis to the control variables, which showed a significant negative correlation between the labor unionization rate and CSR at the $1 \%$ level. This indicates the managers' general tendency towards CSR when unions' influence is stronger, which is maintained even after controlling for sample selection bias.

Table 7. Robustness test: Heckman two step.

\begin{tabular}{|c|c|c|c|}
\hline & \multirow{2}{*}{$\begin{array}{c}\text { OLS } \\
(\text { UNION1 }=1)\end{array}$} & \multicolumn{2}{|c|}{ Heckman Two-Step } \\
\hline & & First Stage & Second Stage \\
\hline VARIABLES & CSR & UNION1 & CSR \\
\hline WORKAGE & & $\begin{array}{c}0.034^{* *} \\
(2.132)\end{array}$ & \\
\hline UNION2 & $\begin{array}{c}-0.018^{* * *} \\
(-2.927)\end{array}$ & & $\begin{array}{c}-0.018^{* * *} \\
(-3.004)\end{array}$ \\
\hline LNSIZE & $\begin{array}{c}0.007^{* * *} \\
(6.546)\end{array}$ & $\begin{array}{c}0.280 * * * \\
(5.232)\end{array}$ & $\begin{array}{c}0.007^{* * *} \\
(4.598)\end{array}$ \\
\hline$L E V$ & $\begin{array}{c}-0.037^{* * *} \\
(-3.867)\end{array}$ & $\begin{array}{l}0.817 * \\
(1.787)\end{array}$ & $\begin{array}{c}-0.036^{* * *} \\
(-3.673)\end{array}$ \\
\hline$R O A$ & $\begin{array}{c}0.058 * * \\
(2.114)\end{array}$ & $\begin{array}{l}-2.503 \text { ** } \\
(-1.966)\end{array}$ & $\begin{array}{l}0.055^{*} \\
(1.902)\end{array}$ \\
\hline$M B$ & $\begin{array}{c}0.005^{* * *} \\
(3.259)\end{array}$ & $\begin{array}{c}0.058 \\
(0.721)\end{array}$ & $\begin{array}{c}0.005^{* * *} \\
(3.359)\end{array}$ \\
\hline FOR & $\begin{array}{c}0.009 \\
(1.015)\end{array}$ & $\begin{array}{c}0.190 \\
(0.444)\end{array}$ & $\begin{array}{c}0.009 \\
(1.055)\end{array}$ \\
\hline Constant & $\begin{array}{l}0.498^{* * * *} \\
(24.595)\end{array}$ & & $\begin{array}{l}0.488^{* * *} \\
(15.140)\end{array}$ \\
\hline IMR (Inverse Mills ratio) & & & $\begin{array}{c}0.004 \\
(0.367) \\
\end{array}$ \\
\hline Year fixed effects & YES & YES & YES \\
\hline Industry fixed effects & YES & YES & YES \\
\hline Observations & 482 & 675 & 482 \\
\hline
\end{tabular}

$* * *, * *, *$ indicate respectively significance at the $1 \%, 5 \%$, and $10 \%$ levels or better.

To sum up the empirical results, labor union influence is negatively associated with CSR, and this negative association is more pronounced in the non-owner manager group in Korea. Further, this association is valid according to several robustness tests, such as quantile regression, 2SLS regression, and Heckman two-step regression.

We compare our empirical result with Chun's [33] paper and our correlation analysis is consistent with prior papers. So, when we analyze univariate correlation then CSR is positively and significantly associated with the size of the firm, return on assets, market to book and foreign ownership. Further, 
the leverage ratio is negatively and significantly associated with CSR and this is also consistent with prior paper [8]. In sum, univariate correlation is a qualitatively similar result with prior papers.

\section{Conclusions}

This paper used firm-year level labor union data and CSR for a sample of Korean listed firms. The empirical results suggest labor union existence and the labor unionization rate have a negative relationship with CSR activity. Additionally, this negative association is more pronounced in the non-owner manager group. These results are also consistent for quintile regression analysis. Therefore, we can interpret that labor unions allure managers to decrease CSR activity to obtain higher short-term earnings to maximize their wage. Mostly non-owner managers agree with labor unions because of the non-owner managers' incentive system in Korea, which is short-term earnings based. Further, we conducted a 2SLS regression and Heckman two-step testing, the empirical results being consistent with the main findings.

As most empirical studies, our research has some limitations. Although we attempt to address concerns about the possible weakness in causality between labor unions and CSR and on the endogeneity in CSR and labor union influence by adopting 2SLS, the main results are not completely free of these concerns to the extent that the main variables of interest are determined endogenously, and the true levels of labor union influence and CSR are measured with errors by proxies. Additionally, there is an unpredictable limit to the same outcome at different times in addition to the analysis period of this study. Notwithstanding, we believe that the consistent results from various robustness analyses ameliorate these concerns and corroborate the negative relationship between labor union influence and CSR. This study is only an early stage of the related sustainability literature. If labor union data can be updated, future research will expand the analysis period and analyze whether there is a change in the relationship between labor union influence and CSR. Future research should suggest how labor union influences CSR in more detail. In addition, we plan to look further into how the labor union influence impacts corporate giving, which is a direct measure of CSR. In this study, we do not conduct qualitative approach such as interviews with labor union leaders or make any questionnaires to labor unions to support quantitative analysis. So future research related to labor union should conduct qualitative and quantitative analysis at the same time, which would enhance the validity of the result.

Author Contributions: H.-M.C. and S.-Y.S. designed the research papers; H.-M.C. and S.-Y.S. analyzed and collected the data; H.-M.C. and S.-Y.S. wrote the paper. H.-M.C. and S.-Y.S. contributed equally in this paper.

Conflicts of Interest: The authors declare no conflict of interest.

\section{References}

1. Carroll, A.B. A three-dimensional conceptual model of corporate performance. Acad. Manag. Rev. 1979, 4, 497-505. [CrossRef]

2. Milgrom, P.; Roberts, J. Price and advertising signals of product quality. J. Polit. Econ. 1986, 94, 796-821. [CrossRef]

3. Beatty, R.P.; Ritter, J.R. Investment banking, reputation and the underpricing of initial public offering. J. Financ. Econ. 1986, 15, 213-232. [CrossRef]

4. Ghoul, S.; Guedhami, O.; Kwok, C.; Mishra, D. Does corporate social responsibility affect the cost of capital? J. Bank. Financ. 2011, 35, 2388-2406. [CrossRef]

5. Fombrun, C.; Shanley, M. What's in a name? Reputation building and corporate strategy. Acad. Manag. J. 1990, 33, 233-258.

6. Waddock, S.A.; Graves, S.B. The corporate social performance-financial performance link. Strat. Manag. J. 1997, 18, 303-319. [CrossRef]

7. Johnson, R.; Greening, D. The effects of corporate governance and institutional ownership types on corporate social performance. Acad. J. Manag. J. 1999, 42, 564-576.

8. Oh, W.Y.; Chang, Y.K.; Martynov, A. The effect of ownership structure on corporate social responsibility: Empirical evidence from Korea. J. Bus. Ethics 2011, 104, 283-297. [CrossRef] 
9. Barnea, A.; Rubin, A. Corporate social responsibility as a conflict between shareholders. J. Bus. Ethics 2010, 97, 71-86. [CrossRef]

10. Sulkowski, A.J.; Edwards, M.; Freeman, R.E. Shake Your Stakeholder: Firms Leading Engagement to Cocreate Sustainable Value. Org. Environ. 2017, 16, 1-19. [CrossRef]

11. Freeman, R.; Medoff, J. The Two Faces of Unionism; NBER working papers; The NBER Labor Studies Program: Cambridge, UK, 1979.

12. Chen, H.J.; Kacperczyk, M.; Ortiz-Molina, H. Labor unions, operating flexibility, and the cost of equity. J. Financ. Quant. Anal. 2011, 46, 25-58. [CrossRef]

13. Chyz, J.A.; Leung, W.S.; Li, O.Z.; Rui, O.M. Labor unions and tax aggressiveness. J. Financ. Econ. 2013, 180, 675-698. [CrossRef]

14. He, J.; Tian, X.; Yang, H. Labor Unions and Payout Policy: A Regression Discontinuity Approach; Working paper; Social Science Research Network: Rochester, NY, UAS, 2014.

15. Hilary, G. Organized labor and information asymmetry in the financial markets. Rev. Account. Stud. 2016, 11, 525-548. [CrossRef]

16. Bradley, D.; Kim, I.; Tian, X. Do unions affect innovation? Manag. Sci. 2016, 63, 2251-2271. [CrossRef]

17. Chun, H.; Shin, S. Labor union and real earnings management. Glob. Bus. Financ. Rev. 2017, $22,30-49$. [CrossRef]

18. Jensen, M. Value maximization, stakeholder theory, and the corporate objective function. J. Appl. Corp. Financ. 2010, 22, 8-21. [CrossRef]

19. Banning, K.; Chiles, T. Trade-offs in the labor union-CEO compensation relationship. J. Labor Res. 2007, 28, 347-357. [CrossRef]

20. Shin, Y.; Tinaikar, S.; Zhang, Y. The Impact of Labor Unionization on Corporate Overinvestment and Underinvestment; Working paper; Social Science Research Network: Rochester, NY, USA, 2016.

21. Bryan, D.B. Influence of Organized Labor on Audit Quality and Internal Control; Working paper; Florida State University: Tallahassee, FL, USA, 2016.

22. Chung, R.; Lee, B.B.; Lee, W.J.; Sohn, B.C. Do managers withhold good news from labor unions? Inst. Oper. Res. Manag. Sci. 2015, 62, 46-68. [CrossRef]

23. Hirch, T. Firm investment behavior and collective bargaining strategy. Ind. Relat. 1991, 31, 95-121. [CrossRef]

24. Cho, H.; Lee, B.; Lee, W.; Sohn, B. Do labor unions always lead to under-investment? J. Manag. Account. Res. 2017, 29, 45-66. [CrossRef]

25. Karier, T. Unions and monopoly profits. Rev. Econ. Stat. 1985, 67, 1335-1364. [CrossRef]

26. Ruback, R.S.; Zimmerman, M.B. Unionization and profitability: Evidence from the capital market. J. Polit. Econ. 1984, 92, 1134-1157. [CrossRef]

27. Lewis, H.G. Union Relative Wage Effects: A Survey; University of Chicago Press: Chicago, IL, USA, 1986.

28. Connolly, R.A.; Hirsch, B.T.; Hirschey, M. Union rent seeking, intangible capital and market value of the firm. Rev. Econ. Stat. 1986, 68, 567-577. [CrossRef]

29. Jensen, M.C.; Meckling, W.H. Theory of the firm: Managerial behavior, agency costs and ownership structure. J. Financ. Econ. 1976, 3, 305-360. [CrossRef]

30. Schwab, S.J.; Thomas, R. Realigning corporate governance: Shareholder activism by labor unions. Mich. Law Rev. 1998, 96, 1018-1094. [CrossRef]

31. Aguilera, R.V.; Rupp, D.E.; Williams, C.A.; Ganapathi, J. Putting the S back in corporate social responsibility: A Multilevel Theory of Social Change in Organizations. Acad. Manag. Rev. 2007, 32, 836-863. [CrossRef]

32. Oh, S.; Hong, A.; Hwang, J. An analysis of CSR on firm financial performance in stakeholder perspectives. Sustainability 2017, 9, 1023. [CrossRef]

33. Feng, Y.; Chen, H.H.; Tang, J. The impacts of social responsibility and ownership structure on sustainable financial development of China's energy industry. Sustainability 2018, 10, 301. [CrossRef]

34. Matten, D.; Moon, J. "Implicit" and "Explicit" CSR: A Conceptual Framework for a Comparative Understanding of Corporate Social Responsibility. Acad. Manag. Rev. 2008, 33, 404-424. [CrossRef]

35. Campbell, J.L. Why would corporations behave in socially responsible ways? An institutional theory of corporate social responsibility. Acad. Manag. Rev. 2007, 32, 946-967. [CrossRef]

36. Porter, M.; Mark, K. The Big Idea: Creating Shared Value. How to reinvent capitalism-And unleash a wave of innovation and growth. Harv. Bus. Rev. 2011, 89, 2-17. 
37. Kinderman, D.P.; Lutter, M. Explaining the Growth of CSR within OECD Countries: The Role of Institutional Legitimacy in Resolving the Institutional Mirror vs. Substitute Debate; Max Planck Institute for the Study of Societies Discussion Paper; Social Science Research Network: Rochester, NY, USA, 2018.

38. Dawkins, C.E. A test of labor union social responsibility: Effects on union member attachment. Bus. Soc. 2016, 55, 214-245. [CrossRef]

39. Amihud, Y.; Lev, B. Risk reduction as a managerial motive for conglomerate mergers. Bell J. Econ. 1981, 12, 605-617. [CrossRef]

40. Salancik, G.R.; Pfeffer, J. Effects of ownership and performance on executive tenure in U.S. Corporations. Acad. Manag. J. 1980, 23, 653-664.

41. Chun, H.M. Corporate international diversification and corporate social responsibility: Evidence from Korean firms. Asian Soc. Sci. 2014, 21, 54-63. [CrossRef]

42. Hategan, C.-D.; Sirghi, N.; Curea-Pitorac, R.-I.; Hategan, V.-P. Doing Well or Doing Good: The Relationship between Corporate Social Responsibility and Profit in Romanian Companies. Sustainability 2018, 10, 1041. [CrossRef]

43. Lee, J.; Kim, S.J.; Kwon, I. Corporate social responsibility as a strategic means to attract foreign investment: Evidence from Korea. Sustainability 2017, 9, 2121. [CrossRef]

44. Peterson, M. Estimating Standard Errors in Finance Panel Data Sets: Comparing Approaches. Rev. Financ. Stud. 2009, 22, 435-480. [CrossRef]

45. Chen, M.C.; Lee, C.F.; Huang, C.M. The effects of corporate social responsibility on equity fund returns: Evidence from China. Int. J. Econ. Financ. 2016, 8, 92. [CrossRef]

46. Heckman, J.J. The common structure of statistical models of truncation, sample selection and limited dependent variables and a sample estimator for such models. Ann. Econ. Soc. Meas. 1979, 5, 475-492.

(C) 2018 by the authors. Licensee MDPI, Basel, Switzerland. This article is an open access article distributed under the terms and conditions of the Creative Commons Attribution (CC BY) license (http:/ / creativecommons.org/licenses/by/4.0/). 